\title{
University education of the educational professionals: from the "edu-myths" to the social impact
}

\section{Ramon FLECHA`, Nerea GUTIERREZ`, Laura RUIZ-EUGENIO`}

We decide to start this article with the narrative of Laura Ruiz-Eugenio due to the coincidence that in 1999, the year in which the first issue of the Journal of Educational Science was published, she graduated in Social Education and began to collaborate in CREA's researches. We include at the end, the story of Nerea Gutierrez as one of the researchers who more recently has been linked to the line of research on educational actions evidence-based.

\section{The seminars of CREA "with the book in hand"}

In 1999, the year in which the first issue of the Journal of Educational Sciences was published, I graduated in Social Education at the University of Barcelona. In September of that same year, Ramon Flecha, professor at the same university and founder of CREA, invited me to participate in the theoretical seminars "with the book in hand". Shortly after, I started working in FACEPA, Federation of Cultural and Educational Associations of Adult People.

These seminars had been done in CREA twice a month since its starting in 1991. Works not only from the main authors of the social sciences and hummanities such as Habermas (1987), Freire (1970) and Merton (2010/1973) are read but from other disciplines. We have read Rita-Levi Montalcini (1988) in medicine, Eric Kandel (2012) in neuroscience and Stephen Hawking (1988) in theoretical physics. In each session, the pages of the work that have previously been agreed upon are discussed. Participation is very wide, from people who work at university such as Professors, PhD candidates and undergraduate students, as well as teachers and other professionals involved in entities and social and educational movements.

Each participant, as long as they have read the work, regardless of their academic level, can participate in the debate. The interventions start from a paragraph that the person has previously selected. When starting the intervention, the person reads the paragraph indicating the page where he/she

\footnotetext{
- Ramon Flecha-Professor DHC, School of Sociology, University of Barcelona ramon.flecha@ub.edu

- Nerea Gutierrez-University of Barcelona

- Laura Ruiz Eugenio-Ramon e Cajal Felow, Department de Teoria i Historia de

L'Educacio, University of Deusto lauraruizeugenio@ub.edu
} 
is and then makes his/her contribution. The debate is based on an egalitarian dialogue in which contributions are valued according to their arguments and not according to the power position of the person who makes them. This way, it overcomes one of the handicaps that sometimes take place in the social sciences, such as talking about works that have not been read. One of the most famous cases was that of Althusser who ended up recognizing that when he wrote Reading Capital, he had not read Capital, but only had read his first volume and knew very little about Marx (Althusser, 1992: 196-197).

In these theoretical seminars, I discover a great contrast between the initial training I had received at the University and the needs as a professional of education that I find in FACEPA. University education in Spain, especially in areas such as education, has been far from the scientific evidences that had been shown to have a social impact. The students could graduate and even finish the Masters and the Doctorate without knowing the main international databases and the best academic journals. We graduated without knowing about the existence of these magazines because they had hidden them from us. This has a lot to do with the feudal model of Spanish universities in which the people who could be promoted in the academy were those who submitted to the Professor. CREA broke with that submission and was founded following the guidelines of the international scientific community, advised by the best universities in the world as well as by some of its main authors such as Robert Merton, creator of the sociology of science. Since its beginnings, CREA had the aim of generating a scientific research capable of identifying theories and practices that overcome inequalities and train professionals of the highest teaching and research excellence, coming from different ethnic groups, genders, ages and social classes. This is how CREA achieved its first challenge, creating an open, diverse, interdisciplinary and ethical centre that broke with the feudal chain of the Spanish university system. Currently, the academic in social sciences in Spain has changed a lot. Others joined in its transformation, but there are still those who resist the scientific evidence in education, clinging to the feudal structures of some faculties.

I was lucky that during my student period I could meet with teachers like Ramon Flecha and other people from CREA who not only read the main authors in the social sciences, but also included the evidences in their research, as well as generating research that had a social impact. Participating in the seminar "with the book in hand" opened me the door to training as an evidence-based education professional and, in this way, to be able to implement educational actions that help to reverse situations of social inequality.

The Romanian Institute for Adult Education of the West University of Timisoara was another research centre that, like CREA, has based its research on scientific evidence for social impact. IREA is a pedagogic research institute in the field of adult and continuing education, aiming to provide scientific and methodological support for all adult education institutions in Romania and to establish the link between the academics and practitioners in adult learning 
area. The overall research aim is to improve the quality of the education for adults, and to identify ways to enhance their ongoing participation in learning, and for strengthening the lifelong learning dimension both at individual and institutional level.

From the beginning of the 2000s, CREA and IREA also began a history of collaboration. In the last 20 years, they have developed more than 10 research projects jointly with other universities within the framework of various European programs such as Socrates, Leonardo and Erasmus. IREA has participated in the research conducted by CREA, the RTD WORKALO (20012004) and the Integrated Project INCLUD-ED (2006-2011) of the fifth and sixth Framework Research Programs of the UE to which we will return later. The RTD and the Integrated Projects were the mechanisms of those research framework programs for the promotion of high-quality research, aimed at contributing to the resolution of social, economic and technological problems of European societies. The researches in which CREA and IREA have collaborated jointly with other European research centres have been aimed at providing scientific evidence that promotes the professionalization, the education of adults, the participation and the social inclusion of people from the most disadvantaged groups.

In the seminars of CREA and collaborating in the researches they were developing, I discovered theoretical arguments and scientific evidences that fit the professional needs of FACEPA and I was aware that the training I had received at university was not evidence-based but on "edu-myths". For example, I had the opportunity to participate with Professor Flecha in the development of the publication "Adult and adult learning" (Flecha \& Ruiz, 2000) incorporating the latest contributions on the learning capacity of adults throughout the life, thus overcoming discrimination based on age and a learning perspective based on deficits.

\section{WORKALO: reseach by and with the Roma}

At that time CREA was working on what it would be the WORKALO project (2001-2004). Due to its rigor and the knowledge it provided, it had a great political, scientific and social impact. WORKALO also offered to the professionals of the education very valuable evidences to promote an education of adults that would contribute to the discrimination that for centuries the Roma people had suffered.

WORKALO was the first RTD project, Research and Technological Development, of all the framework programs of the European Commission, focused on analysing the situation of the European Roma population. WORKALO was the antecedent of INCLUD-ED (2006-2011), the project of greater scientific rank and with more resources of the Framework Programs of the European Commission dedicated to school education, to which I will also refer later. In addition to IREA, two other European research centres from the University of Surrey in the United Kingdom and the Higher Institute for Social Services of 
Lisbon in Portugal, as well as representatives of the Roma community in Europe participated in WORKALO.

The exclusion suffered by the Roma people has also occurred in the investigations that have been carried out on them. WORKALO and INCLUD-ED have been developed reverting this exclusionary tendency, including the voices of the Roma people in the process of developing these investigations. This has allowed identifying more rigorously, in both projects, the strategies that have followed the Roma people who have managed to successfully overcome social exclusion (Flecha, 2014). One of the mechanisms that were carried out for the inclusion of the voices of the Roma people was the creation of an advisory council formed by Roma people. The voices of the Roma people were not only present in the extensive field work that was carried out but also in each of the reports done, which when prepared, were reviewed and approved by the advisory council before its publication. In this way, it was not only possible to validate the results, but also to prevent the ethnocentrism that many researches about the Roma people had fallen.

In the four years that the research lasted, elements were identified in two key aspects. On the one hand, the situations that Roma people have to face when they look for work and the strategies they usually use to integrate themselves in the job market were the basis for actions and employment programs that were not only worked from the technical field, but also collecting interests and motivations of the Roma people, collaborating directly and actively with them. On the other hand, proposals for improvement in areas such as education, eliminating the ethnic segregation of European schools, an equal education for all respecting cultural specificities have been included in various decrees approved by the Parliament of Catalonia, in the European Parliament and in the Congress of Deputies of the Government of Spain (Sorde, Flecha and Mircea, 2013).

One of the ideas that usually emerged in the different countries where the fieldwork was carried out was the advancement of the Roma people in Europe and throughout the world, towards a progressive recognition as a people without territory. The World Conference against Racism was held in Durban in November 2001. In that conference, representatives of different Roma organizations contributed the definition of themselves as the "Romà", a community united by a common culture in different countries of the world that has neither claims nor State nor territory (IRU, 2001). In Durban they also claimed their right to have their people recognized and to be called the "Romà" people in all parts of the world.

A few months after the Durban Conference, the Parliament of Catalonia unanimously approved the resolution 1046 / VI: (1). It recognizes the identity of the Roma people and the value of their culture as a safeguard of the historical reality of this people. (2). Urges the Government to take the necessary steps to help spread the recognition of the Roma culture and its value to Catalan society (BOPC, 2001). This recognition was the prelude to the current Integrated Plan 
of Roma People in Catalonia, a pioneering political deployment in the world for having involved transversally all the governmental departments of the Government of Catalonia, for having a budget and, for showing a strong involvement of the Roma civil society from their beginnings (Gomez et al., 2019).

The presentation of the results of the WORKALO project took place in April 2004 in the European Parliament. A resolution on the situation of the Roma people in the territory of the European Union was presented in the chamber, which included the conclusions and orientations of this project (European Parliament, 2005). The results of this project also reached the Spanish Court. In September of 2005 a proposal for the recognition of the rights of the Roma people was presented, promoted by a parliamentarian who attended the presentation of the results in Brussels in 2004 (Congress of Deputies, 2005). In Spain, the political impact of WORKALO also gave way to the creation of advisory bodies that include Roma people, such as the State Council of the Roma People, to which any measure that affects this group is consulted, before being implemented. The European Council has also collected the contributions made by WORKALO highlighting the importance of working with and for the Roma people, as well as encouraging the EU Member States to include the Roma community in the elaboration of any measure aimed at their protection, fight against anti-Gypsyism and social exclusion (Council of Europe, 2009).

In the last decade there has been a shift in the international scientific community towards a greater recognition of the Roma experience and the research teams already have the participation of Roma people (Amador, Flecha and Sorde, 2018; Aiello, Flecha and Serradell, 2018). For example, in those investigations that have been carried out due to the processes of Roma immigration from Eastern European countries, such as Romania, to Spain (Sorde et al., 2013).

The political impact that WORKALO had in Europe, led Ramon Flecha to be named Doctor Honoris Causa by the West University of Timisoara in 2007. Dozens of researchers who had been Ramon's students travelled to Timisoara to avoid losing the act of investiture. There his family and the professors Simona Sava and Teodor Mircea Alexiu of West University accompanied him. It was an act full of science, humanity and feeling, like everything that surrounds the contributions of Ramon.

By then, it was barely a year since I have achieved a scolarship to do my PhD. Afther those years participating in CREA's seminar and collaborating in some of its researces, I had clear that I wanted to direct my doctorate towards the educative actions based on evidcences that were getting to have a social impact. This way, my doctoral thesis was linked to the university education evidencebased of the educational professionals.

\section{INCLUD-ED: educational actions evidence-based}

At the same time, I was able to participate in the integrated project "INCLUDED. Strategies for inclusion and social cohesion from education in Europe" 
(INCLUD-ED Consortium 2006 - 2011; Flecha, 2015). The purpose of INCLUDED was to provide scientific knowledge to achieve academic success and social cohesion for all children and communities in Europe, regardless of their socioeconomic status and ethnic origin.

We know that in today's information society, education is a powerful resource to overcome social exclusion. However, many of the educational systems in Europe are not getting good results. The knowledge obtained with INCLUD-ED helps to reverse this situation by providing scientific evidence on those social and educational actions that are already contributing to overcoming educational and social exclusion.

The scientific evidence provided in INCLUD-ED promoted educational and social policies not based on occurrences but on scientific evidence of the actions that had the best results in overcoming school failure, problems of coexistence and exclusion in areas such as housing, health, employment, and social and political participation. Like WORKALO, INCLUD-ED was based on the communicative methodology including the voices of the most vulnerable groups throughout its process of research development, especially youths, migrants, cultural minorities. For example, Roma people, women and people with disabilities were taken into account.

INCLUD-ED involved 15 universities from 14 European countries developing 20 case studies in effective educational practices and 6 longitudinal case studies of communities involved in learning projects - and which have demonstrated to achieve excellent results. INCLUD-ED identified Successful Educational Actions (SEAs), that is, those actions that can improve school success, values, emotions and feelings in each context in which they are implemented (Flecha, 2015).

SEAs, as effective and transferable solutions based on scientific evidence, have contributed to develop both educational theories, successful practices and evidence-based policies. The results of INCLUD-ED have been included in several resolutions of the Parliament and the European Council. Some of them are the Council conclusions of the 11 of May 2010 on the social dimension of education and training (2010 / C 135/02); the Communication from the EC (January 2011) 'Tackling early school leaving: A key contribution to the Europe 2020 Agenda'; the Council Recommendation on policies to reduce early school leaving (June 2011) (10544/11); the European Parliament resolution of 2 April 2009 on educating the children of migrants (2008 / 2328 (INI)); and the European Parliament resolution of 9 March 2011 on the EU strategy on Rome inclusion (2010/2276 (INI)).

INCLUD-ED was the only social science research that the European Commission has included in the list of the 10 best European researches of recent times (European Commission, 2011). The scientific social and political impact of INCLUD-ED allowed me to access a research support from the Government of Catalonia to carry out a research stay for two years at the Institute for Education, Community and Society of the University of Edinburgh. The research project developed at UoE was on educational actions that are contributing to overcome social inequalities in the field of health, housing, empoyment and social and 
political participation in Catalonia and Scotland (Government of Catalonia, 2012-2014; Ruiz-Eugenio, 2016).

In turn, having acquired that international experience in my research career gave me the opportunity of being selected by the Ramon y Cajal program of the Spanish Government to re-join to the University of Barcelona as a researcher for a period of five years. Currently, I continue working from the University of Barcelona on educational research committed to overcome social inequalities, within the framework of what is today CREA, a Community of Research of Excellence for All. In 2015, gathered in assembly, CREA members decided to transform us from being a Research Centre to a research community within the framework of the international scientific community. This community is made up of members from different research groups, universities and countries from different scientific disciplines. With this transformation, CREA continues to advance towards the scientific and human excellence that has characterized the research it has carried out since its origins.

\section{IMPACT-EV and Scientific Literacy}

European and world scientific research advances in the line of a communicative methodology that had been developed in WORKALO and INCLUD-ED with the concept of co-creation; including citizenship in the whole process of research development, as well as in the definition of the answers to the European social, economic and technological problems. But it also moves towards social impact (Flecha, Soler-Gallart and Sorde, 2015).

The social impact of INCLUD-ED contributed to the European Commission selecting the project "IMPACT-EV. Evaluating the impact and outcomes of European SSH Research (Flecha, 2014-2017) ", also directed by Ramon Flecha, as one of the investigations to finance in the seventh Framework Program of Research. The main objective of IMPACT-EV has been to develop a monitoring and evaluation system for the different impacts of research in social sciences and humanities. Nevertheless, IMPACT-EV has not only developed indicators and standards to evaluate the scientific impact of SSH research, but also its political and social impact. Understanding social impact as social improvements achieved because the implementation of the results of a particular project or research study. Our societies have already defined the challenges and objectives of society (such as the objectives of the EU 2020, the UN Millennium Goals, etc.) and need researches that create knowledge to develop them.

The result of the work carried out in IMPACT-EV is SIOR (Social Impact Open Repository). This is an open and free access repository to display, share and store the social impact of the research results. SIOR responds to a growing demand that society makes to science and scientists that advances that are having a social impact are within the reach of all citizens (Pulido et al., 2018). SIOR has also contributed to the advance towards the scientific literacy of the population, in line with one of the most revolutionary transformations that have 
taken place in the history of science. This comes hand in hand with the Open Access movement. Currently, any scientific evidence that has obtained public

resources must be published in open access in the next 10 days. Anyone anywhere in the world can have access to scientific knowledge.

From the movement of democratic education of adults in Spain, there is also progress towards the promotion of scientific literacy of the most vulnerable groups. For example, FACEPA is jointly developed with La Verneda-St. Marti Adult School the "ScienceLit project: Scientific literacy for all!" That during the 2016-2018 period obtained funding from the ERASMUS + program of the European Commission. This project also involved organizations from Germany, Greece and Slovenia. Its purpose is to promote and disseminate scientific knowledge in society, especially among the most vulnerable groups such as young people and women without university qualifications. This scientific literacy is carried out through one of the successful educational actions that identified INCLUD-ED, the dialogic gatherings. In the dialogic scientific gatherings, people without academic degrees are reading scientific works and articles. Non-university people through reading and dialogue are acquiring scientific knowledge that has a direct impact on their lives. For example, the collective knowledge they create in these discussions helps them make better decisions about their health. However, it is also having a direct impact on improving their capacity for argumentation based on science, as well as respecting the contributions of the people who participate.

This revolution in the scientific world, leads to the knowledge of the successful educational actions is available to everyone, not only the professionals of education but families, neighbourhoods and the most disadvantaged communities. This is what has happened in more than 3000 schools around the world that are implementing successful educational action

\section{Training new generations of young researches in scientific and human excellence}

Rocio Garcia-Carrion was another of the researchers who was trained with Ramon Flecha in CREA, linking her doctoral thesis to one of the INCLUD-ED case studies. Both of us developed the doctoral thesis practically during the same years at the University of Barcelona. Shortly after presenting the thesis, she also had the opportunity to do a postdoctoral research at the University of Cambridge. The research project, with which she was selected within the Marie Curie Actions of the Framework Program for European Research, deepened the implementation of two of the successful educational actions identified by INCLUD-ED, the Interactive Groups (IG) and the Dialogic Literary Gatherings (DLG) as learning environments. Back from Cambridge, Rocio wins one of the most prestigious contracts in the Basque Country's research plan, the Ikerbasque contract, as well as a Ramon y Cajal contract. These contracts lead her to continue developing her research career at the University of Deusto and open a line of research on IG and DLG there. There is currently a lot of scientific literature on the impact of IG and DLG on the improvement of learning, values, 
emotions and feelings (Garcia-Carrion, Molina and Roca, 2018; Garcia-Carrion, Molina-Luque and Molina-Roldan, 2018; Villardon-Gallego et al., 2018).

The IG are the form of organization of the classroom that, at present, gives better results in the improvement of learning and coexistence. Within the same classroom, the students are divided into small heterogeneous groups in terms of learning level, cultural origin and gender. An adult person is responsible for invigorating the interactions that occur in each of the small groups. This person can be either another teacher, a relative, a member of the community or a volunteer, for example, a student of the university. In each group, they perform an activity of 15 to 20 minutes long about some instrumental content such as language, mathematics or science. When the time runs out, the group changes both of volunteer and activity. Therefore, in an hour the whole group highlights four or five activities. In IG, interactions are multiplied, and learning is accelerated while increasing the effective work time. Being heterogeneous groups, some of them finish the activity before the others. That is when the adult person promotes his/her help to those who have not yet finished, not giving them the solution, but helping them in the resolution process. These interactions improve and consolidate the learning of everyone, not just of those who find it more difficult. The most advantaged students also learn because it is known that we consolidate our learning when we have to explain it to others. Nevertheless, not only they improve instrumental learning, but they also improve in values because solidarity is not only something that can be talked about but is part of their day-to-day life in IG.

DLG are an educational activity that takes place both with adults and in preschool, primary and secondary education. In these gatherings the best literary creations of humanity are read. The adults read the original works and the children read works adapted to their age of very high quality. As in the other dialogic gathering, the group decided the work to be read and the pages to be read prior to the gathering session. Each participant has to select a paragraph and relate it to some reflection, relating it with his or her daily experience. In the DLG both adults and children have read works such as Ulysses, Arabian Nights and Don Quixote. The egalitarian dialogue on which these gatherings are based, creates a climate of trust in which all opinions are respected and valued. There is much evidence on how DLG have had an impact on the improvement of language learning and literacy, as well as an impact on the improvement of values, emotions and feelings.

As Ramon Flecha did in CREA, Rocio created a "seminar with the book in hand" in the Faculty of Education of Deusto. This seminar was soon joined by other researchers and students who moved because they wanted to link their academic career to scientific evidences.

Nerea Guitierrez is one of them. Nerea studied her Bachelor Degree both in Primary and Early Childhood Education and her Master Degree in Learning and Teaching of Spanish in Multilingual and International Contexts. In 2017 met Rocio at Deusto University and started participating in the theoretical seminar. 
When meeting Rocio and the seminar, Nerea found the IG and the DLG. She decided then to start her PHD in Dialogical Pedagogical Gatherings and English learning in the initial formation of Primary Education teachers. This is how she summarizes it:

"The experiences that I have had during my educational background had left a mark on me by a clear distinction of roles depending on the position, academic experience and age you had; A vertical structure like this triggered struggling with team work. However, I had the great fortune of running into a person who showed me that the rules of the Academy were made by people and that cooperation didn't depend on age or academic achievements, but on feelings between people. This was a turning point in my life as this person showed me that with interactions based on egalitarian dialogues and rowing all to one, the success could turn greater, which would imply a greater benefit in the training of children. This person I speak of had two qualities, very special and essential, always integrated into her speeches. The first one is that she never spoke in the first person singular; she would always made reference to "us", to teamwork, to the network of collaboration, to the group of mates thanks to which she had reached all her goals. The second is that all the research she carried out was based on scientific evidence with social impact, which meant the goal of everything she had done was focused on the improvement of education, feelings, values, thus, the life of children and, in general, society.

This was something I admired from the very beginning and that helped me, even more if possible, to value all the work she had been doing and to know that I wanted to be part of it...and that is how I ended up knowing more about the Successful Educational Actions (SEAs).

My first contact was with the DLG in a seminar that was held once a month with colleagues from the Faculty. It was a magical space where we left aside the chores of everyday life to enter into a story that we might had never come to understand in the same way by ourselves. It was a moment in which all the participants had a voice, all our contributions were valued, which made me wish to play an active part in the work carried out and share reflections. Luckily, it is a space that still exists nowadays and to which little by little new faces have joined. After that, the Multidisciplinary International Conference on Education Research arrived at the university where I work, and I was lucky to be able to participate as a volunteer and get a little closer to the research that was being done in the area of education, research based on evidences. Afterwards, I was given the opportunity to participate in the seminars "with the book in hand", to attend the meeting of learning communities, the congress of gatherings, the video forums, etc. It caused such an impact on me and meant that much to me that we decided to choose the topic of my PHD around a theme that emerges from them, thus obtaining opportunities to develop my career around this subject. It is a great pleasure for me that I had the chance to start developing my career as a young researcher, surrounded by people who believe and rely on me. People who work to improve education, with actions that are having a social 
impact and that have demonstrated that truly improve both people lives and the relationships between them."

Ramon Flecha throughout his research career and in the last 20 years, manage to face a feudal university, breaking its walls and the "edu-myths" in the way in which the future professionals of education were trained. He has helped to train education professionals and young researchers from the scientific and human excellence. Others recognize its relevance and follow his guidelines by training our students, future professionals of education in the best scientific evidences that will improve many people's lives.

\section{References}

Amador, J., Flecha, R., Sorde, T. (2018). Drugs and Mental Health Problems among the Roma: Protective Factors Promoted by the Iglesia Evangélica Filadelfia. International Journal of Environmental Research and Public Health, 15(2), 335.

Aiello, E., Flecha, A., \& Serradell, O. (2018). Exploring the Barriers: A Qualitative Study about the Experiences of Mid-SES Roma Navigating the Spanish Healthcare System. International Journal of Environmental Resesearch and Public Health, 15(2), 377.

Althusser, L. (1992). El porvenir es largo. Barcelona: Destino.

BOPC (2001). Butlletí Oficial del Parlament de Catalunya. Resolution 1046/VI Del Parlament de Catalunya, Sobre El Reconeixement de la Identitat del Poble Gitano i del Valor de la seva Cultura. 5è periode. 6aㅡ legislatura. Número 240, p. 41: Parlament de Catalunya, 2001.

Congress of Deputies (2005). Proposición no de ley relativa al reconocimiento de los derechos del pueblo gitano (Proposal not of Law regarding the Recognition of the rights of the Romà). Diario de sesiones del Congreso de los Diputados. Legislatura VIII, 27 de Septiembre, 2005, no114, 5761-5768.

Council of Europe (2009). Roma and Travellers. Working with Roma to improve their own Lives. Paris: Council of Europe.

European Commission (2011). Added value of reserach, Innovation and Science portfolio. European Commission - MEMO/11/520 19/07/2011 Retrieved from http://europa.eu/rapid/press-release_MEMO-11-520_es.htm?locale=fr Accessed June 21, 2019.

European Parliament (2005). European Parliament resolution on the Situation of Roma in Europe and Marking the International Roma Day, PE 357.314v01-00, P6_TA-PROV (2005) 0151, 20 April, 2005.

Flecha, R.; Ruiz, L. (2000). Aprendizaje adulto y adultez. Postgrado de nuevas perspectivas en formación de personas adultas. Fundació Pere Tarrés: Barcelona.

Flecha, R. (2014). Using Mixed Methods from a Communicative Orientation: Researching with Grassroots Roma. Journal of Mixed Methods Research, 8(3), 245-254.

Flecha, R. (2014-2017). IMPACT-EV. Evaluating the impact and outcomes of European SSH Research. 7th Framework Programme. European Commission.

Flecha, R. (2015). Successful Educational Actions for Inclusion and Social Cohesion in Europe. Barcelona: Springer.

Flecha, R., Soler-Gallart, M., \& Sorde, T. (2015). Social impact: Europe must fund social sciences. Nature, 528, 193

Freire, P. (1970). Pedagogy of the Oppressed. New York: Continuum. 
Garcia-Carrion, R., Molina, S. \& Roca, E. (2018). Interactive Learning Environments for the Educational Improvement of Students With Disabilities in Special Schools. Frontiers in Psychology, 9(1744). DOI: 10.3389/fpsyg.2018.01744

Garcia-Carrion, R., Molina-Luque, F., \& Roldán, S. M. (2018). How do vulnerable youth complete secondary education? The key role of families and the community. Journal of Youth Studies, 27(14), 701-716. DOI: 10.1080/13676261.2017.1406660

Gomez, A., Padros, M., Rios, O., Mara, L.C. \& Pukepuke, T. (2019). Reaching Social Impact Through Communicative Methodology. Researching With Rather Than on Vulnerable Populations: The Roma Case. Frontiers in Education, 4(9).

Goverment of Catalonia (2012-2014). Socio-educational Actions to Overcome Inequalities. Beatriu de Pinós Programme. Ref. 2011 BP_A 00348

Habermas, H. (1987). The theory of communicative action. Lifeworld and system: A critique of funcionalist reason. Boston, MA.: Beacon Press.

Hawking. S. (1988). A Brief History of Time: From the Big Bang to Black Holes. New York: Bantam.

INCLUD-ED Consortium (2006-2011). INCLUD-ED. Strategies for inclusion and social cohesion from education in Europe. INTEGRATED PROJECT Priority 7 of Sixth Framework Programme. European Commission.

IRU (2001). Retrieved from http://www.unionromani.org/notis/2001/new2001-0903.htm

Kandel, E. et al. (2012). Principles of Neural Science. New York: McGraw-Hill.

Levi-Montalcini, R. (1988). In Praise of Imperfection: My Life and Work. New York: Basic Books.

Merton, R. (2010). Sociology of Science and Sociology as Science. New York: Columbia University Press.

Pulido, C. Redondo-Sama G., Sorde, T., Flecha R. (2018). Social impact in social media: A new method to evaluate the social impactof research. PLOS ONE, 13(8): e0203117. DOI: $10.1371 /$ journal.pone.0203117

Ruiz-Eugenio, L. (2016). Integrative Actions to Overcome Poverty in Scotland: Teenage Mothers, Single Families and Muslim Women. Multidisciplinary Journal of Educational Research, 6(3), 208-230.

Sorde, T., Flecha, R., Mircea, T.A. (2013). The Roma People. A global identity without territory. Scripta Nova, xvii (427). Retrieved from http://www.ub.es/geocrit/sn/sn427/sn-427-3.htm

Sorde, T., Serradell, O., Puigvert, L., \& Munte, a. (2013). Solidarity networks that challenge racialized discourses: The case of Romani immigrant women in Spain. European Journal of Women's Studies, 21, 87-102

Villardon-Gallego, L., Garcia-Carrion, R., Yañez-Marquina, L., \& Estavez, A. (2018). Impact of the Interactive Learning Environments in Children's Prosocial Behavior. Sustainability, 10(2138). DOI: 10.3390/su10072138

Schools as Learning Communities official web sites https://www.comunidaddeaprendizaje.com.es http://utopiadream.info 